\title{
Analysing News Coverage on Homosexuality in Malay Language Newspapers in Malaysia, 1998-2012
}

\author{
SYAMSUL ZAHRI SUBIR \\ Tunku Abdul Rahman University College
}

\begin{abstract}
Homosexuality is a complex issue in Malaysia, owing to its identity as a conservative nation with a Malay-Muslim majority. Here, homosexuality is not only unrecognised but also negatively viewed by society. Unsurprisingly, the homosexuality issue is not widely covered in the news media in Malaysia. However, changes in local political climate and communication technology require researchers to evaluate the current literature. Furthermore, the number of researches, particularly homosexuality coverage in the Malaysian media remains insignificant. This study attempts to draw a deeper understanding of how newspapers in Malaysia are utilised in constructing homosexuality coverage by employing a modified version of Huckin's study (2002) of qualitative content analysis. A random sample of 463 homosexuality coverage was collected from two Malay language newspapers, Utusan Malaysia and Berita Harian spanned from 1998 to 2012. The findings revealed that homosexuality coverage are largely social-cultural-political themes intertwined, supported by official government and religious sources with the coverage mostly not geared towards the progressive content, politically motivated and dominantly narrated in Islamic widespread pitch. This study argues that homosexuality coverage was constructed in such a way to serve the interest of dominant Malay political hegemony while the normative definition of sexuality remains to be heteronormative patriarch from the long history of the patriarchal institution. This study concludes by challenging the media as a 'cultural resource' that 'inherently' homophobic. The study suggests that media should work in ubiquitous and consider redefining the role, particularly in 21st-century democratic Malaysian nations.
\end{abstract}

Keywords: Homosexuality, Malaysia, newspaper, news media, qualitative content analysis.

\section{INTRODUCTION}

This study seeks to explore the homosexuality coverage in Malaysian newspapers particularly from the perspective of two Malay language newspapers, namely Utusan Malaysia and Berita Harian from the period of 1998 to 2012. As a social institution, media is a reflection of the dominant ideology influenced by the role of discourse as the prevalent ways of looking at certain events. Following the long historical background of both Utusan Malaysia and Berita Harian with strong Malay political hegemony and ideology, how do these newspapers depicted homosexuality coverage and how their ideology plays the role in the production of the concerned discourse?

This study is significant for several reasons. According to Foong and Ahmad (2010), stories of sensitive issues such as race, religions and sexuality can at times unintentionally misrepresent and mislead in the media, and thus, created conflicts and intense reactions especially in societies with diverse beliefs and cultures. Mustafa (2010) claimed that in a diverse society, difficulty and the complexity exists in tackling the provocative issue in providing accurate coverage on religion, ethnicity, sexuality or any other issues seen as proactive. 
Hence, it is worth studying homosexuality coverage in Malaysian media because many open questions can be explored specifically into the cultural production of the news in confronting this controversial issue. In addition, previous research often discussed on social issues such as ethnicities and religion conflict and how the issues were depicted in the media are to be compared with homosexuality issues (Shaari et al., 2006; Fong, et al., 2010). For this purpose of the study and for the sake of variety, terms such as "homosexual", "gay" and "same-sex sexuality" are used interchangeably and as a range of sexual expressions.

\section{Homosexuality in Malaysia}

\section{LITERATURE REVIEW}

Malaysia does not recognize same-sex unions nor has anti-discrimination laws for homosexuality and any deviant sexual orientation. Those convicted of homosexuals sex act can be punished with fines, imprisonment and caned (Hamidah, 2004). Besides the civil law, Malaysia also practice Islamic law known as Syariah law, which is clear in criminalising homosexuals. Hence, homosexuality is often seen as a crime in Malaysia. Malaysia is a multi-confessional country with Islam being the largest practised religion and exercised a dual system of law that includes secular and Syariah law as a moral code and religious law of Islam. Syariah law deals with topics including issues of crime, politics and economics among Muslim.

According to Ho (1998), homosexual activities have been around in Malaysia for a long period but it was barely discussed widely in the mainstream media. The studies of homosexuality in Malaysia only started to receive attention during the 1990s. Jackson and Sullivan (2001) posited that the emergence and spread of gay visibilities in Malaysia as in most Asian countries was linked with the multiple influences and effects of globalisation, industrialisation and urbanisation in which these developing countries in Asia are adapting their lifestyle and economy to fit in with the western capitalism (Altman, 1996, cited by Sullivan, 2001).

However, it is argued that homosexuality in Malaysia cannot always be conflated with the influences of western countries. This is due to the basis that homosexuality in Malaysia has already existed in the form of pondan or mak nyah tradition and their good acceptance and tolerance among transsexuals in a traditional Malay village dated back a few decades ago. It was supported by Teh (2002) that "most mak nyah had a better standard of living during the colonial days. Most of them work as mak andam (bride's attendant), joget dancers, cook and artistes".

Recent development on the studies of homosexuality in Malaysia showed an interesting entrants with most of discussion revolved around homosexuality in aspects of health, policy, religion and psychology as evidence in which local academics started to give attention on this subject and the community (Brown, Low, Tai \& Tong, 2015; Dzulkifli, Rokis \& Abdul Rahim, 2018; Lim et al., 2018; Liow, Khalaf, Ameeruddin, \& Foong, 2017; Stephen, 2016; Yusof, Kadir, Ibrahim \& Puji, 2015; Zulkifli \& Rashid, 2016; Zulkifli \& Rashid, 2019).

\section{Homosexuality and Media}

While there is relatively little literature on homosexuality and the studies of media in Malaysia, the contentions on the subject demonstrate curiosity on how homosexuality is being depicted. However, there have been some significant studies with the current entrants (Alagappar, 2009; Goh, 2014; Leon \& Jintalan, 2018; Zainon \& Kamila, 2011). Media in Malaysia started to give attention on homosexuality issues during the trial of the former 
Deputy Prime Minister, Anwar Ibrahim for the sodomy allegation in September 1998 that becomes the highlight in most mainstream news media in Malaysia.

Anwar Ibrahim's case created huge controversy and the public uproar and the wide coverage on his sodomy allegation was intentionally being sensationalised in the media to destruct his image (Nagata, 1980) especially from the government-controlled media (Spaeth, 1998). The coverage on Anwar Ibrahim sodomy trial was seen as a basis of prevalence of homosexual discourse among the public in Malaysia as Chua (2007) argued that the excessive exposure on homosexual stories from both local and international media is to be believed the main influence of public attitudes toward this group.

As claimed by Lipkin (1994) when issues related with homosexuals was addressed in the media, it is reported in stereotypical and sensationalised ways that conflates homosexuality with controversy and sometimes suffering or uses their identity to make fun and humiliation. The portrayal of this sexual-oriented minority group made by the selection of negative words and connotations by the local news media can be understood as discursive devices in broader social debates within Malaysian society.

Accordingly, a report published in the official website of The International Gay \& Lesbian Human Rights Commission (IGLHRC) revealed that homosexuals community in Malaysia had always been depicted in a humiliating way in most Malaysian news media with derogatory words including terms such as songsang (deviant), lucah (explicit) and jijik (disgusting). These terms had been alternately used as choices of words among reporters in most series of coverage to describe this group. The commission claimed these as a form of discrimination and hatred on gay people in the country (IGLHRC, 2010). These discriminatory labels used in the local coverage had prompted a loose coalition of Malaysian human right activists. Thus, they have sought the help of the Human Rights Commission of Malaysia or known as SUHAKAM (Surahanjaya Hak Asasi Manusia Malaysia) in putting a stop to local news media's unethical, biased and systematic discrimination (IGLHRC, 2010).

Given these points, it drawn to the attention into the broad-spectrum questions of how were newspapers in the country have presented homosexuality issues to their readers to the equally important question of how the newsmakers determine the stories for constructing homosexuality coverage. What makes these newsmakers use these words and language to describe homosexual people? Do media present their real life? Are media attempting to discipline homosexuals through stereotypes and repression by using these derogatory terms? Or, do these stereotypes serve another purpose? What do these descriptions and accounts signify to society at large?

\section{THEORETICAL FRAMEWORK}

\section{Social Constructionism}

Social constructionism takes a stance towards the way people accept and understand the system in this world. A central focus of social constructionism is to hold the ways on how individual or group perceived the construction of social reality and how they participate in the social system. A social system is a "product that should belong to the societies and (they) prefer to be in that way" rather than being something which is immutable (Crossley, 2005).

Social constructionists are particularly interested in social phenomena with the disconcerting concepts, texts, practices and conceptual schemes from individuals or groups from varies places and times. Following Burr (2003), the theory argued that individuals or 
groups of the similar background often take the concept for granted and claims as it is naturally established and constructed in such ways such as gender, class, and race. Burr (2003) also added that social constructionism could happen in the phenomena experienced by the people or among themselves upon inspection to be found and to be socially maintained. As a consequence, members of a similar setting usually shared the same meaning which is constructed through social interaction with others using the shared language.

Dunphy (2000) writes that social constructionism also plays a significant part in meaning-making or work as metaphors that can give impact and inform the power relations among the society. When it comes to social issues, for example, the shared meanings become subjective based on how the issue is interpreted. Furthermore, social issues can be defined in multiple ways depending on those who provide the explanations. Social issues that involved ambiguity, deviant or unnatural are not inherent but it was socially constructed. It can be changed and alter based on who owns it. What is unusual might be normal to someone else and vice versa.

The social constructionist model specifies four tools which are symbolic codes or language, which refer to the way on how the words and context of certain events being depicted. The second tool is cultural traditions that referred to the cumulative deposit of beliefs, value, attitudes, religion and material objects or possessions acquired by a group of people within the course of generations. Next is cognitive customs that was described as the way of how certain events were formed and labelled by the media as the way it is, merely to let people think as such. Lastly is shared roles and rules as a set of behaviours that are expected by individuals or group that holds a particular status to guide action. These four tools shape the ways people experience and talk about the world.

Figure 1 illustrates the social construction model. The discussion on social constructionism is very significant in this study specifically on how the construction of the narrative on homosexuality coverage in the media as a set of social meaning and how the issues are being constructed through communication and the context used. As some scholars have revealed that social constructionism is normally employed to marginalise and to oppress certain members of the population, a study of feminists and queer theory is prominently design and created to naturalise the inequality and the conflict arises toward the concept of social constructionism.

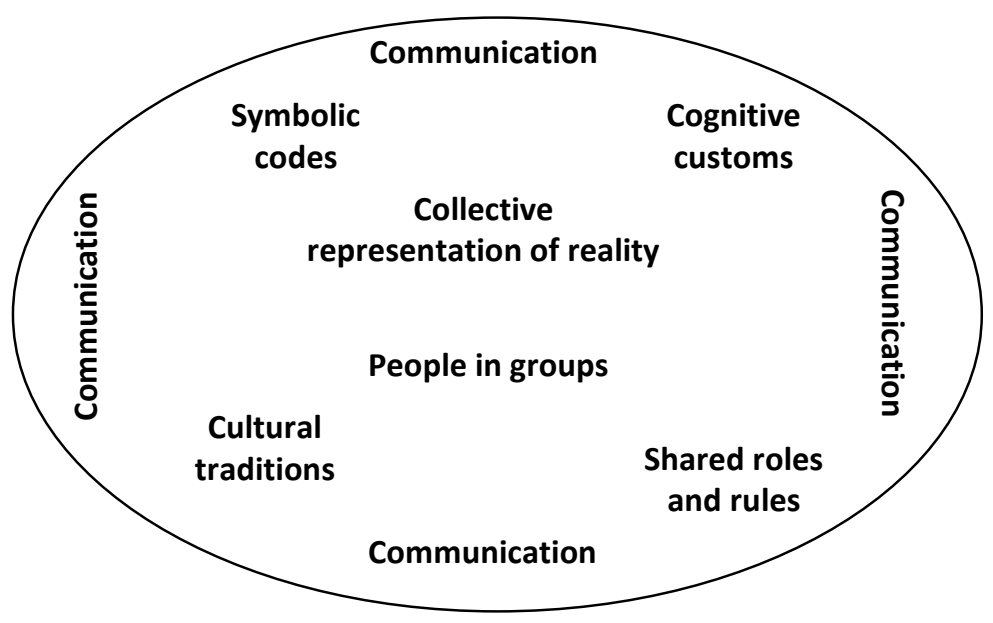

Figure 1: Social Construction Model 


\section{Research Design}

\section{METHODOLOGY}

This study is qualitative research in nature. In a qualitative research study, interpretation is an essential requirement for obtaining meaningful results. Qualitative content analysis was employed to identify the characteristics and cultural meaning of homosexuality and its dispute as they emerged in the news narratives. The study utilised the inductive approach from the initial observations that first made through all the collected coverage to generate the themes.

\section{Data Sampling}

Two prominent Malay language newspapers in Malaysia namely Utusan Malaysia and Berita Harian were selected for data sampling. This study focus on these Malay language newspapers, aimed to explore the dominant pattern and discursive themes of homosexuality from the Malay hegemonic discourse, knowing these newspapers were predominantly associated with a long tradition of championing Malay agenda and ideologies (Fee, 2001). Using "homosexuality", "homosexual", "gay" and "lesbian" as the search term, a total of 463 coverage were sampled from the year 1998 to 2012. The year of 1998 is selected as Alagappar and Kaur (2009) stated homosexuality begun to be the subject of local news media that entered the mainstream after the year 1998 from Anwar Ibrahim's trial on sodomy accusation which resulted on the attention garnered from Malaysian news media. The unit of analysis was the single coverage on homosexuality stories.

\section{The Construction of the Themes}

The method conducted was adapted from the modified version of Huckin's study, which he employed qualitative content analysis to demonstrate how manipulative silences work in coverage of homelessness (Huckin, 2002). Following the approached used by Huckin (2002), the process of the construction of the dominants themes on homosexuality coverage consists of four steps. For the first step, all 463 coverage were reviewed to gain familiarity and highlighted ideas that appeared important upon initial reading. Interpretative questions of what, who, how and why regarding content of the coverage surfaced on homosexuality was being raised numerously as patterns in the content began to emerge. The second step is doing the coding process. All homosexuality issues within each coverage were mapped out and deconstructed that led to the inference of four main categories contributed to the denotation on homosexuality (Table 1). The four main categories were (i) traits of homosexuality, (ii) causes of homosexuality, (iii) effects on homosexuality and (iv) responses towards homosexuality. The third step is to resubmit all selected coverage to a more detailed reading that will further defined all meaning within four main categories. The process was conducted with note being taken on how homosexuality issues were being revealed that later consigned to several subcategories and forming the Content Matrix (Figure 2).

The Content Matrix was used to conduct a more thorough coding of the news texts. Each text was given a qualitative, conceptual analysis rather than just a scan for keywords, thereby avoiding a standard criticism of traditional content analysis as being merely a tabulation of lexical items. Having a classification of the discourse on homosexuality within the four main categories, the subcategories were then identified and listed, noting which ones is included and which ones are not that later construct the dominant pattern and the 
discursive themes of homosexuality coverage from both newspapers. For the fourth step, the frequency of occurrence of each subcategory was determined and their relative weight in each main topic. Finally, as the analysis progressed and all elements are identified, all subcategories were grouped and classified the coverage to formulate the dominant pattern and discursive themes of the coverage. The frequency of occurrence of these subcategories and the subject identifiers were then summarised and examined to highlight their relative contribution.

Throughout the coding process of identifying the main category, subcategories and the discursive themes, two coders were involved through 'negotiated inter-coder reliability' method who met to discuss their coding with the researcher. Ten percent of the total coverage from each coder was randomly selected and independently coded by the alternate rater. The code is constructed by all coders followed by the discussion to arrive at a final version in which, most if not all coded messages have been brought into alignment.

Table 1: The four main category with the list of selected subcategories

\begin{tabular}{|c|c|c|}
\hline Main Category & $\begin{array}{l}\text { Subcategories } \\
\end{array}$ & Theme \\
\hline \multirow[t]{4}{*}{$\begin{array}{c}\text { Traits of } \\
\text { homosexuality }\end{array}$} & $\begin{array}{ll}\text { - } & \text { Islam against homosexuality } \\
\text { - } & \text { The biggest and serious sin } \\
\text { - } & \text { The practice of Prophet Lut/Lot's people }\end{array}$ & Religion \\
\hline & $\begin{array}{l}\text { - } \text { Against the regular norm } \\
\text { - } \quad \text { Illicit and immoral behavior } \\
\text { - } \quad \text { Degrading self-respect and human culture } \\
\text { - } \quad \text { Against the value of marriage }\end{array}$ & Social and moral \\
\hline & - Using human rights as an issue & Human rights \\
\hline & $\begin{array}{l}\text { - Hedonism from the western countries } \\
\text { - Western modernisation and lifestyle }\end{array}$ & Western influences \\
\hline \multirow[t]{3}{*}{$\begin{array}{c}\text { Causes of } \\
\text { homosexuality }\end{array}$} & $\begin{array}{l}\text { - } \quad \text { Lack of religion education } \\
\text { - } \quad \text { Not using religion as guidance }\end{array}$ & Religion \\
\hline & $\begin{array}{l}\text { - } \quad \text { Growing numbers of entertainment premises } \\
\text { - } \quad \text { Media influences }\end{array}$ & Social and moral \\
\hline & $\begin{array}{l}\text { - Western propaganda } \\
\text { - } \quad \text { Economic capitalism } \\
\text { - Influence from secular ideology }\end{array}$ & Western influences \\
\hline \multirow[t]{2}{*}{$\begin{array}{c}\text { Effects of } \\
\text { homosexuality }\end{array}$} & $\begin{array}{l}\text { - } \quad \text { Threatening the basic value of family } \\
\text { - } \quad \text { Affect national identity } \\
\text { - } \quad \text { Pose a threat to the country } \\
\text { - } \quad \text { Increase of divorce cases }\end{array}$ & Social and moral \\
\hline & $\begin{array}{l}\text { - History will repeat time of Prophet Lut/Lot } \\
\text { - } \quad \text { Damaging the Islam's image } \\
\text { - } \quad \text { Detrimental to Muslim }\end{array}$ & Religion \\
\hline
\end{tabular}


Jurnal Komunikasi: Malaysian Journal of Communication Jilid 35(4) 2019: 83-100

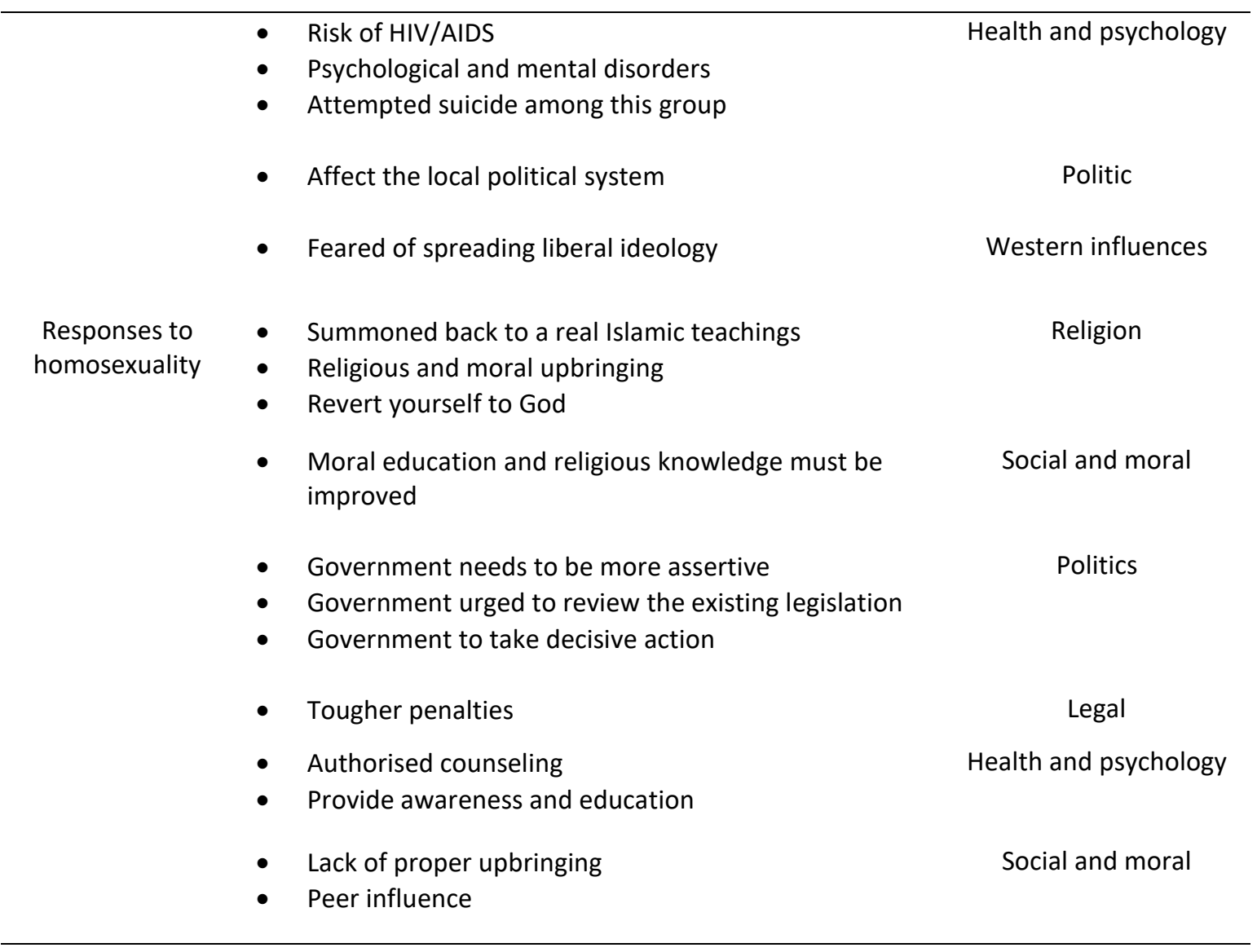

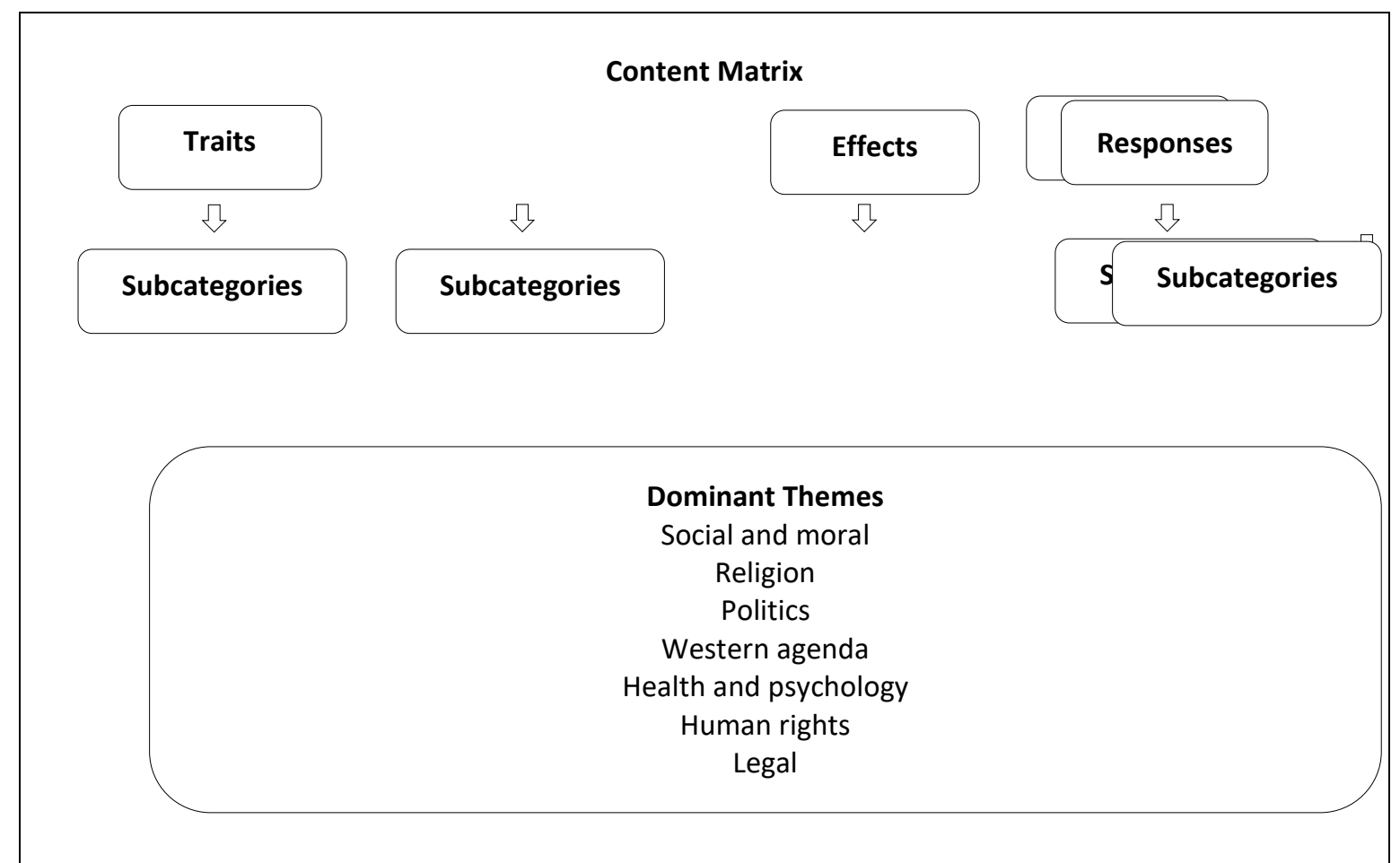

Figure 2: The Content Matrix 


\section{RESULTS}

For the discussion of the findings, the researcher offers a sample of direct quotes from the news texts that exemplify how they describe, construct, produce and/or reproduce their subject position. However, it should be noted that all the original excerpts and quotations were in Malay language hence all quotations were translated into English language and undergo the process of paraphrasing. As a result, the language may not have flawless correspondences where every word and phrase was comparable with a foreign equivalent though of course some cases come closer than others (Lee, 2014).

\section{Social and Moral: Threats to Family Institution}

Most of the coverage was largely focus on the effects of homosexual sex behavior as the main categories with negative connotation. It was observed that both newspapers were often and extensively disparaged homosexual sex behavior with the accentuated to the harmful influence on the family institution. For instances, Utusan Malaysia stated that homosexuality can ruined the family institution and asserted that "(homoseksualiti) bukan sahaja terpesong dari sistem kemanusiaan sejagat malah merosakkan sistem sosial dan institusi kekeluargaan" ((homosexuality) not only deflected from the system of universal humanity but even damage the social system and the family institution) (28 April 2012, p. 12).

Another example of the effects of homosexual sex behavior can be seen from an excerpt which stated "jika dilihat daripada perspektif yang lebih besar, budaya ini akan merosakkan sistem sosial dan sistem keluarga" (if it is viewed from the larger perspective, this culture will corrupt the social and the family system) (10 May 2012, p. 12). Homosexuality was also perceived as a threat to the foundation of family value and it was also believed to be the reason for divorce in the country, "LGBT juga dilihat sebagai ancaman kepada asas kekeluargaan, apakah peningkatan kes perceraian di Malaysia turut disumbang oleh budaya songsang ini?" (LGBT was also seen as a threat to the institution of family, whether the increase rate of divorce in Malaysia was contributed by this deviant sex culture) (11 March 2012, p. 7).

\section{Religion: Challenge to Religious Tenet}

Most of the coverage within religion theme employed traits of homosexuality as their main categories with lots of religious insight and frequently mentioned Islam that is strictly prohibited same sex relation and homosexual behavior, "sama ada keadaan yang muncul pada hari ini relevan atau tidak, perbuatan homoseksual tetap haram dalam Islam" (whether this is relevant in today's world or not, homosexuality is still prohibited in Islam) (16 January 2012, p. 5). Another trait of homosexuality asserted by Utusan Malaysia relates homosexuals sex act as similar act of adultery, "perbuatan homoseksual sama erti dengan zina yang jelas merupakan perbuatan fasik dan haram di sisi Islam" (homosexual sex act is equal to adultery that an impious behavior and forbidden in Islamic teaching) (26 February 2001 , p. 5). Both newspapers also clearly indicated that Quran is very explicit in the condemnation of homosexuality behavior and stated that, "Islam secara jelas menentang kumpulan yang dipanggil gay, lesbian, dan biseksual dan ia dinyatakan dalam nas-nas alQuran dan Hadis" (Islam is clearly against the gay, lesbian and bisexual group and it is stated in Quran and Hadith) (21 August 2011, p. 7). 
Another example of homosexuality traits within this theme is referring them as Lut/Lot's people in relation with the prophet Lut/Lot (pbuh), who preached against homosexuality in the cities of Sodom and Gomorra that were destroyed and demolished causes by the widely same sex practiced by the people. The portrayal of homosexuals' sex act and the elaboration on the similitude with Lot's people were eloquently narrated in the newspapers with the coverage quoted, "Kaum Nabi Luth adalah kaum yang sering melakukan maksiat iaitu homoseksual. Kaum lelaki cenderung kepada kaumnya sendiri. Ini bermakna, mereka berasmara dengan kaum sejenis lantas mengadakan hubungan seks sejenis" (Lot's people is known as people who practicing homosexual. Men are attracted to the same gender. This is means they makes love to the same gender and had same-sex intercourse) (9 July 2004, p. 6).

\section{Politics: Biasness in the Political Discourse}

Most coverage was heavily highlighted to the prompt action or responses to homosexuality as the main categories by stressing the government to ascertain homosexuality activities in the country, probably because both newspapers are government oriented and controlled media. The coverage also demonstrated that any gay individual or a person who practiced the alternative lifestyle has absolutely no room to enter political party and to be elected as politician in Malaysia. In one of the coverage which indicated response to homosexuality, Utusan Malaysia suggested that all political parties in the country to mutually refuse any self-identified gay to hold any position in the political arena and stated that, "semua parti politik di negara ini perlu bersatu mewujudkan undang-undang khusus untuk menolak manusia yang mempunyai naluri songsang daripada menjadi pemimpin supaya kerajaan tidak dipimpin oleh golongan LGBT" (all political party in this country must be unified to embody a specific law that will reject individuals with deviant sexuality as leader so the government is not led by the LGBT community) (10 April 2012, p. 13).

The coverage also revolved around the traits of homosexuality, which surrounded the sentiment of skepticism of (then) opposition parties on their stance towards homosexuality issues. Utusan Malaysia for instance wrote that (then) opposition coalition is a political party that favor to the homosexual community and become the enabler for gay social movement with remarks such as "pembangkang seolah-olah menghalalkan aktiviti LGBT" (opposition seem to legalising the activities of LGBT) (7 June 2012, p. 27). Such remark was made when the (then) opposition was being sermon to frequently questioning the basic human rights issues in this country including the gay rights and posited that "pakatan pembangkang juga mempersoalkan hak kebebasan di negara ini sehingga sanggup membawa agenda gejala lesbian, gay, biseksual dan transgender (LGBT) serta seks bebas yang amat bertentangan dengan nilai etika, budaya dan agama di negara ini" (the opposition party also questions the rights to freedom, to the extent of bringing lesbian, gay, bisexual and transgender agenda (LGBT) as well as free sex that is contrary to the ethics, culture and religion in the country) (23 April 2012, p. 4).

The ramification from the harbor suspicion on the opposition allies towards their stance on homosexuality has resulted in the denunciation towards (then) opposition party especially to their leader. In one of the coverage, Utusan Malaysia delivered bad impression on Anwar Ibrahim, the defacto leader of the (then) opposition coalition with homosexual's sex act and questioned if the allegation can be accepted among opposition party members on the issues as stated, "kita dapat lihat ketika ini, Ketua Pembangkang, Datuk Seri Anwar 
Ibrahim sering dikaitkan dengan budaya songsang itu, adakah pemimpin pembangkang boleh menerima secara terbuka perkara itu?" (as we can see, the head of opposition, Datuk Seri Anwar Ibrahim was often linked to deviant sex act, is that what leaders of the opposition can accept publicly?) (30 June 2012, p. 9). Such statement by the newspaper was made, when Anwar Ibrahim was called up for the interview by the British Broadcasting Corporation (BBC) regarding of the anti-discrimination law on gay community in Malaysia.

\section{Western Agenda: Homosexuality as Western Influence}

Another theme on homosexuality is the contentions that associated homosexual's sex act with Westerns influence and the argument on secularism and liberalism. Most of the coverage used traits of homosexuality as main categories which described homosexual sex act is only normal and a common practice in the Western countries. For example, Utusan Malaysia asserted that, "di Barat hubungan sejenis yang lebih dikenali sebagai homoseksual dan lesbian semakin mendapat tempat di kalangan penduduknya" (In the Western countries, same sex relationship that also known as homosexual and lesbian, is now become prevalent among them) (21 February 2010, p. 9). Meanwhile, Berita Harian stated that, "perjuangan lesbian, gay, biseksual dan transeksual (LGBT) sudah mendapat tempat sehingga sebilangan besar negara Barat memperakui hak diperjuangkan golongan ini" (The belligerence among lesbian, gay, bisexual and transsexual (LGBT) has been well recognised to the point of most Western countries are already acknowledging their rights) (17 September 2012, p. 33).

Causes of homosexuality was also frequently mentioned under this theme when Utusan Malaysia newspaper asserted that Western countries as being the major influence of homosexuals in the country. It is also deliberately stated that Western countries as the major contributor, and as an attempt to incapacitate Muslim majority in Malaysia, "mungkin kerana Malaysia sebuah negara Islam, pelbagai usaha puak anti-Islam dilakukan termasuk menerapkan budaya gay ke negara kita" (maybe because Malaysia is an Islamic state, many attempts of anti-Islamic group was made including propagating the gay culture to our country) (3 January 2011, p. 8). It is further claimed that Westerns countries are responsible to popularised homosexuality as tactics to cripple Islam.

Findings on homosexuality also revolved around the argument on secularism and liberalism. Utusan Malaysia attributed homosexuality to secularism "fahaman sekularisme dan liberalisme merupakan antara faktor yang menyumbang kepada penularan gejala lesbian, gay, biseksual dan transgender (LGBT)" (secularism and liberalism beliefs contribute to lesbian, gay, bisexual and transgender (LGBT)) (5 September 2012, p. 6). This suggests that secularism is said to be a cause to homosexuality development in Malaysia.

\section{Health and Psychology: Homosexuality as Mental Disorder and HIV stigma}

The subject on psychology, mental health and the topics of HIV and AIDS are also among topics being highlighted by the newspapers on homosexuality. Most coverage in the newspapers used traits of homosexuality and labeled them as individuals who suffered from psychological problem, particularly mental and emotional issues. In one of the coverage, Utusan Malaysia asserted that, "jika ditinjau dari sudut perubatan mereka ini adalah kumpulan yang bermasalah dari segi psikologi dan sudah tentu dikelaskan sebagai orang yang sakit. Sakit ini berkaitan dengan emosi, dan dengan kata lain sakit jiwa" (if it is reviewed from the medical perspective, they are a group of people who have psychological 
problems and indeed were classified as sick person. This sickness is related with emotion and in other words as mental illness) (28 April 2012, p. 13).

This remark has been echoed several years earlier and was depicted in an article from Utusan Malaysia in the year 2000, "golongan tersebut juga boleh dikatakan mengalami masalah gangguan jiwa dan mengalami tekanan dalam masyarakat" (these people can also been named as those who suffer from mental disorder and pressure in the society) (18 January 2000, p. 22). It was also highlighted that homosexuals required social support. In one of the coverage, it is asserted that, "mereka ini adalah pesakit yang memerlukan bantuan. Mereka berhak mendapat perkhidmatan kesihatan bagi memulihkan penyakit itu. Kita harus berbuat sesuatu untuk golongan ini" (they are patients who need help. They deserve to get health services to cure their illness. We have to do something for this people) (28 December 2010, p. 18) and further seek for the therapist and counselors with the help from religious bodies so the community will be able to get appropriate attention and care.

Both newspapers also illustrated the relationship between homosexuality and HIV and AIDS stigma. In one of the coverage, Utusan Malaysia highlighted major concern on the infection of HIV and emphasised on the alarming number of HIV carrier among the community, "semakin ramai golongan muda lelaki Melayu dikesan menjadi pengamalhomoseksual sekalipun mengetahui perkara itu ditegah agama dan mendedahkan mereka kepada jangkitan virus HIV" (many Malay men are now practicing homosexual sex act even when they knew that it is prohibited in the religion and thus exposing them to HIV) (23 December 2011, p. 06). In addition to the HIV disease, other sexually transmitted diseases were also mentioned such as syphilis, gonorrhea and more, "gejala perbuatan buruk ini sebelumnya telah menghasilkan penyakit kelamin yang serius dan berbahaya seperti sifilis, gonorrhea dan sebagainya. Namun kesemua penyakit itu tidak ditakuti oleh manusia sebelum kedatangan AIDS" (the symptom of this bad behavior resulted to the more serious venereal disease such as syphilis, gonorrhea and more. But all those diseases were not feared by humans before the arrival of AIDS) (10 June 2005, p. 32).

\section{Human Rights: Gay Rights and Gay Social Movement}

The discussion on homosexuality also revolved around the traits of homosexuality on issues surrounding with gay rights and the freedom of expression among the community. As stated in Berita Harian, "atas dasar hak asasi dan kebebasan, golongan itu mahu masyarakat menerima dan memberi pengiktirafan kepada mereka. Mereka juga mahu pengiktirafan daripada sudut undang-undang negara" (based on rights and freedom, homosexual people want society to accept and give recognition to them. They want the recognition from the viewpoint of legal state law) (7 September 2010, p. 18). It is also deliberated in the newspaper on the contention from the gay community that rights must be guaranteed for every types of people in any gender and sexuality as depicted in the Berita Harian, "bagi golongan ini, hak kebebasan dan hak asasi harus diberikan serta dijamin untuk semua golongan tanpa mengambil kira gender atau orientasi seksual mereka" (to this people, freedom and rights should be given as well as guaranteed to all groups without taken into account their gender or sexual orientation) (7 September 2010, p. 18).

The discussion on the debate about gay rights in Malaysia is also heavily deliberated in the newspapers that intertwined with the attention from the Islamic perspective on human rights issue. It is asserted that the fundamental of human rights which also include 
rights among sexual minority in Malaysia must be grounded on the principle of religion and culture as stated by Berita Harian, "platfom kebebasan hak asasi manusia harus dipandu oleh nilai agama dan budaya masyarakat serta perlu disesuaikan dengan sosio-budaya masyarakat" (a human rights platform must be guided by religion's value and culture, as well as the need to be adapted into society's social-cultural values) (3 November 2011, p. 23). Accordingly, the concept of human rights from the Islamic framework must be compelled according to the Sharia law and it is asserted in the newspapers, "dalam Islam syariah dan figh ada hak asasi tetapi ia mengikut syariah. Hak ialah memperjuangkan kebebasan tetapi bukanlah kebebasan yang membawa kepada kekufuran dan meminta kita melakukan perkara yang tidak senonoh" (in Islamic Sharia and fiqh, there are basic rights but it followed Sharia. Rights is a fight for freedom but not freedom that lead to infidelity and asking us to do indecent things) (23 April 2012, p. 8).

\section{Legal: Law and Legislation on Homosexuality in Malaysia}

It was undoubtedly stated that the country has a clear stance on the issue and considered homosexuality as an offense and utterly prohibited in the country. It was stated in Utusan Malaysia that "kita bernasib baik kerana negara kita mempunyai undang-undang yang mengharamkan amalan keji LGBT" (We are lucky because our country has a law that prohibited the despicable practices of LGBT) (5 May 2012, p. 13) and was also asserted the zero tolerance with no legitimate permission on this behavior as cited in Utusan Malaysia, "tiada peruntukan undang-undang yang membenarkan hubungan sejenis, seks bebas dan perkahwinan sejenis di negara ini" (there is no law and its allocation to allow same sex relation, free sex and same sex marriage in this country) (23 March 2012, p. 10).

The coverage also widely stated the responses to homosexuality and alternately demonstrated greater emphasis on the enforcement and prosecution from the authorities to any gay sexual misconduct. The authority such as Royal Malaysian Police was reported to prohibit any activities related with homosexual sex act and any individuals who engage with the activities. In one of the coverage in Utusan Malaysia, it was asserted that, "Polis Diraja Malaysia (PDRM) tidak pernah berkompromi terhadap aktiviti menyalahi undang-undang dan akan membanteras aktiviti seks songsang secara berterusan, termasuk gerakan lesbian, gay, biseksual dan transgender (LGBT)" (The Royal Malaysian Police will never compromise activities against the law and will combat deviant sexual sex act consistently, including lesbian, gay, bisexual and transgender (LGBT) movement) (13 March 2012, p. 8).

\section{DISCUSSION}

The findings of this study reflected the concept of social constructionism via public's understandings of homosexuals, which created the basis of shared expectations about social reality. With four specifies tools under social constructionism which are; symbolic codes or language, cognitive customs, cultural traditions and shared roles and rules that guide people actions or their knowledge, social constructionism shape the ways people experience and talk about the world with the argument that media help to sustain a culture existing power structure.

Based from the findings, social constructionism of homosexuality from the standpoint of Malay language newspapers largely suggest that it was a challenge to the societal norms, a biasness to the political discourse and a challenge to the religion adherence. Homosexuality was also viewed as a Western influence, as well as a form of mental disorder and disease. Issues of gay rights and debates from the legal point were also 
discussed. Applying social constructionism in the narrative of homosexuality in the newspapers showed that homosexuality is socially stigmatised in such way possibly not to challenge the heterosexual privilege, at least from the argument of the researcher. This is following what asserted by Dunphy (2000) that social issues that is ambiguous is socially constructed and can be expressed in numerous ways depending on those who explains. It can later be changed and altered based on who owns it.

As all four tools of social constructionism were interrelated, the discussion of the findings will be discussed in unified, but divided into subsections to ease readers' understanding. The sections include: (i) negative and unbalance voices (ii) them versus us: the enemy as the "other" and (iii) politically motivated.

\section{Negative and Unbalance Voices}

While most of the homosexuality coverage was constructed in negative depiction with lack of supportive and positive narration in both newspapers, the findings can relate with what was stated by Littlejohn (1992) about the selection of the news and choosing the activity which "establishes the salience of issues or images in the minds of the public" (cited in Akpabio, 2005, p. 174) to highlight that the homosexuality is unacceptable. The disproportion of homosexuality coverage can add to the seriousness and criticalness of the issue and eventually these viewpoints will be implanted to what the general readers might think of. This is also supported by McCombs and Shaw's (cited in Sei-hill Kim, 2002) argument on media emphasis towards certain issues in their coverage by allotting a greater proportion of the news hole to them or by placing them more prominently in the newspaper and this will influence the saliences of these issues among the audience.

Although it is not the main intention of this study to analyse and compare the coverage from multiple newspapers with different ownership and control, it was argued that the news attitudes towards the coverage related with homosexuality should not go merely from one single direction. Rather, it should be a concurrently opening up of room and spaces to discuss and express the diversity of opinions and views. The newspapers should obtain the viewpoint of all relevant parties including the homosexuals themselves and those directly or indirectly involved with the homosexual community to get the better understanding of the phenomena from multiple angles.

\section{Them versus Us}

While both Utusan Malaysia and Berita Harian were inclined to support the government's dominant ideology and policies of the ruling political elite (Muhammed, 2009) and work like the major voice to represent the majority Malay in Malaysia, the findings revealed an involuntary relation between the newspapers with the homosexuals. Throughout the analysis, it is obvious that the findings on homosexuality, opposition party and western countries are led to the construction of 'them' versus 'us'. The 'us' is referred to the majority public particularly Malay Muslim in Malaysia with the newspapers representing on their behalf and 'them' is referred to the opposition parties and the western countries. The use of 'them' here was referred to both opposition parties and western countries because both were repeatedly framed in the newspaper with constant allegation to promote homosexuality which is contravene with Malaysian culture and religion. As consequence, both opposition parties and western countries were being shown as entities that does not reflect the Malay culture and adhere to the Islamic religious principles. 
The findings also emerged another unintended relation between homosexuality with the western nation, which also led to the construction of 'us' vs. 'them'. Homosexuality was often being instigated from the Western cultural construct and the central arguments on homosexuality from both newspapers were regularly linked with the Western lifestyles. Western countries were also allegedly responsible to popularise homosexuality in the country as a part of their hidden propaganda to debilitate Islam. Homosexuality was asserted as one of the major contributor to dwindle majority Muslim in Malaysia that attempted to mislead the majority of the Muslim's faith (aqidah) in Malaysia. By referring 'them' to the western countries within the dispute of homosexuality in Malaysia, it is commonly stated that homosexuality is a part of the Western culture in which the gay community has the freedom to enjoy their lifestyles in those countries which is marked as the dissipated morals if that is being practice in Malaysia.

From the preceding discussion, it can be said that opposition parties and the Western countries were treated as a threat to majority Malay Muslim in Malaysia. As both newspapers were Malay language newspapers catered for Malay based readers, apparently these newspapers might work as dominant voices to the majority Malay if not all and served as a significant platform to represent Malay people in Malaysia. Moreover, the nature and the long history of both newspapers itself also play the central role and implication to Malay community. Due to this reason, both newspapers is referred as 'us' based while both opposition parties and the Western countries were referred as 'them' due to their frequent association with homosexuality which are against the Malay culture and disregard to religious principles. This suggests that the newspapers were propagating the 'them' versus 'us' mindset when constructing homosexuality issue.

\section{Politically Motivated}

As Utusan Malaysia and Berita Harian are both mainstream newspapers in Malaysia that are owned and/or under the control of the parties of the ruling coalition government, clearly the backlashing towards homosexuality are perpetually propagates the agenda and policies of its owners to maintain hegemony of the ruling group. By addressing the opposition parties and the western countries as homosexual protagonists and agent of gay movement with a frequent negative depiction, it will heightened the position of the government which will indirectly attract the majority of Malay public to be in favor to their side.

It was depicted in the newspapers that opposition party was overtly play the dominant role to provide the strong support to the gay community and their rights that was presumely intended to attract votes from the community including the allegation of legalising same sex marriage and their intention to dissolute law to homosexual sex act.

Accordingly, this is what stated by Helena (2003) that coverage of marginalised groups commonly reflect the biases and interests of the power that defines the public agenda. This is also in accordance to McCombs and Shaw's (cited in Sei-hill Kim, 2002) argument that the media emphasise certain issues in their coverage within political discourse by devoting a greater proportion of the news hole to them or by placing their interest more prominently in the newspaper and this emphasis in turn influences the salience of these issues among the readers. Hereby, the researcher come to theorise on the great number of homosexuality coverage specifically towards the year 2012 were intentionally conspired by the (then) government as one of their election campaign strategy by using the media for the preparation of the coming general election that was predicted in 
year 2012 because the role of the media is most evident in the run-up to any election (Rajaratnam, 2009).

\section{CONCLUSION}

Overall, there are several general conclusions that can be drawn from the findings of this study. First, although homosexuality is largely denounced as unnatural both in the secular spaces of Malaysia as well as the sacred ones, the numbers of homosexuality coverage received attention from both newspapers.

Secondly, this study revealed that social-cultural-political aspects have some degree of influence on how homosexuality issues are framed in the media. Based on the available findings, homosexuality coverage were largely intertwined around topics of social, politics and religion which relied heavily on the government officials, Malay based non-government organisations and religious institution as a trustworthy agencies and influential voices.

Third, this study has evidenced that homosexual community has no power and control over the images and degree of representations attributed them as depicted in the coverage. The normative definition of sexuality conveyed remains to be heteronormative patriarchy that largely produced by heterosexual reporters, which only have particular kinds of responses and certain qualities and those who are not celebrated the diversity of sexuality in the country. The description about homosexuality almost often uses negative words and homophobic language.

Fourth, the newspapers do not assist in educating society fairly about homosexuality and do not remain objective or independent. Most coverage did not offer alternative views. Based from the findings, there is not much awareness from the reporters through their write-up about homosexuality, which in general contribute to the lack of understanding.

Finally, it must be stated that this study in no way attempt to imply that the media is either good or bad but rather work in ubiquitous. As a social institution, media occupies every aspect of life although not every social actor has equal entree to employ the media for their purposes. Whether the media outlets are under the control of government or the opposition or independent, it should play an important role in how people understands the diversity in the society including the marginalised groups such as the gay community with balance, fair and unbiased representations.

\section{BIODATA}

Syamsul Zahri Subir is a senior lecturer at Tunku Abdul Rahman University College. His research interests include media sociology, digital culture, critical theory, online activism, and participatory culture. Email: syamsulzahri@tarc.edu.my 


\section{REFERENCES}

Alagappar, P. N., \& Kaur, K. (2009). The representation of homosexuality: A content analysis in a Malaysian newspaper. Language in India, 9.

Bahas segera tolak pemimpin LGBT. (2012, April 10). Utusan Malaysia, p. 13.

BBC News. (2011, August 22). Malaysia's Anwar Ibrahim defiant at sodomy trial. Retrieved from www.bbc.co.uk/news/world-asia-pacific-14611879

Berita Harian. (2012, April 23) Fitrah manusia tolak LGBT.

Berita Harian. (2012, September 17) LGBT runtuh institusi keluarga.

Berita Harian. (2012, September 26) Mudah tersasar tanpa 'antibodi' Islam.

Berita Harian. (2011, November 3) Perjuangan tuntut pengiktirafan homoseksual, lesbian tiada faedah.

Berita Harian. (2010, September 7) Perjuangan hak golongan sejenis cemari prinsip kita.

Berita Harian. (2010, December 28) Iktiraf gay umpama menggadai agama.

Boo, S. L. (2011, April 19). "Sissy boot camp" violates law, says Shahrizat. The Malaysian Insider. Retrieved from www.themalaysianinsider.com/malaysia/article/sissy-bootcamps-violates-law-says-shahrizat/

Burr, V. (2003). Social constructionism. London: Routledge.

Brown, J., Low, W. Y., Tai, R., \& Tong, W. T. (2015). Shame, internalized homonegativity, and religiosity: A comparison of the stigmatization associated with minority stress with gay men in Australia and Malaysia. International Journal of Sexual Health, 28(1), 2836.

Crossley, N. (2005). Key concepts in critical social theory. Sage Publications: London.

Dzulkifli, M. A., Rokis, R., \& Abdul Rahim, A. (2018). Gender identity crisis of the millennial generation in Malaysia: Special focus on the issue of pengkid. International Journal of Asian Social Science, 8(10), 819-827.

Dunphy, R. (2000). Sexual politics. An introduction. Edinburgh: Edinburgh University Press.

Fee, L. K. (2001). The construction of Malay identity across nations Malaysia, Singapore and Indonesia, Bijdragen tot de Taal-Land-en Volkenkunde, 157(4), 861-879.

Foong, Y. L., \& Ahmad, S. (2010). Covering religious conflict in Malaysia: How Sin Chew Daily framed the Lina Joy controversy. Jurnal Pengajian Media Malaysia, 12(2), 11-22

Goh, J. N. (2012). Mak nyah bodies as sacred sites: Uncovering the queer bodysacramentality of Malaysian male-to-female transsexuals. Cross Currents, 62(4), 512521.

Hamidah, A. (2004, February 8). United Nation ill-advised on homosexual laws. Retrieved from http://www.glapn.org/sodomylaws/world/malaysia/mynews035.htm

Ho, V. (1998, October 21). Malaysian group launches antigay movement: In Sodom laws. Retrievedfrom http://www.glapn.org/sodomylaws/world/malaysia/mynews001.htm

Huckin, T. (2002). Textual silence and the discourse of homelessness, Discourse \& Society, 13(3) 347-372.

Hui, T. B. (2012). Retrieved from https://core.ac.uk/download/pdf/48653792.pdf

Ibrahim, Z. (2011). Tribute to Aleesha (alias Ashraf). Free Malaysia Today. Retrieved from www.freemalaysiatoday.com/2011/08/02/tribute-to-aleesha-alias-ashraf/

International Gay \& Lesbian Human Rights Commission (IGLHRC). (2010, September 21). Progress seen after protest against media discrimination of LGBT people in Malaysia. Retrieved from http://www.iglhrc.org/content/progress-seen-after-protest-againstmedia-discrimination-lgbt-people-malaysia 
Leon, J. A. D., \& Jintalan, J. (2018). Accepted or not: Homosexuality, media, and the culture of silence in the Philippine society. Jurnal Komunikasi: Malaysian Journal of Communication, 34(3), 408-425.

Lim, S. H., Brown, S.-E., Shaw, S. A., Kamarulzaman, A., Altice, F. L., \& Beyrer, C. (2018). "You have to keep yourself hidden": Perspectives from Malaysian Malay-Muslim men who have sex with men on policy, network, community, and individual influences on HIV risk. Journal of Homosexuality, 67(1), 104-126.

Liow, J. W., Khalaf, Z. F., Ameeruddin, N. A. M., \& Foong, A. (2017). The experience of intimate relationships among homosexual men in Malaysia. Sexuality \& Culture, 21(4), 1140-1156.

Littlejohn, S. W. (1992). Theories of human communication. Belmont, California: Wadsworth Publishing Company.

Michael, S. (2011, March 18). Lady Gaga "gay anthem" censored in Malaysia. The Guardian. Retrieved from www.guardian.co.uk/music/2011/mar/18/1ady-gaga-born-this-waymalaysia

Mustafa, K. A. (2010). Epilogue. In Loo, E. G. \& Mustafa, K. A. (Eds.), Journalism in good faith: Issues and practices in religion reporting (pp.196-201). Shah Alam: Marshall Cavendish (Malaysia) Sdn. Bhd.

Nagata, J. (1980). Religious ideology and social change: The Islamic revival in Malaysia. Pacific Affairs, 53(3), 405-39.

Rajaratnam, U. (2009). Role of traditional and online media in the 12th general election, Malaysia. The Journal of the South East Asia Research Centre for Communication and Humanities, 1(1), 33-58.

Shah, S. (2011, January 10). Malaysia's gay threat. The Nut Graph. Retrieved from www.thenutgraph.com/malaysias-gay-threat

Spaeth, A. (1998, November 16). Whose trial? TIME World. Retrieved from www.time.com/time/world/article/0,8599,2053873,00.html

Stephen, F. M. (2016). Gay identity construction of ten Muslim male undergraduates in Penang, Malaysia: A Phenomenological Qualitative Study. Asia-Pacific Social Science Review, 16(2), 113-119.

Sullivan, G., \& Jackson, P. (2001). Gay and lesbian Asia: Culture, identity, community. Journal of Homosexuality.

Sullivan, G., (2001). Variations on a common theme? Gay and lesbian identity andco mmunity in Asia. In Sullivan G. \& Jackson P.vA. (Eds.), Gay and lesbian Asia. NY: Harrington Park Press.

Teh, Y. K. (2002). Country report: Malaysia, transgender ASIA Research Centre. HK: University of Hong Kong. Retrieved from http://web.hku.hk/ sjwinter/TransgenderASIA/country_report_malaysia.htm

Utusan Malaysia. (2012, January 16) Homoseksual tetap haram.

Utusan Malaysia. (2012, March 6) Kahwin sejenis boleh huru-harakan institusi keluarga.

Utusan Malaysia. (2012, March 11) Penyakit rosakkan bangsa.

Utusan Malaysia. (2012, March 13) JAKIM pantau laman web seks songsang.

Utusan Malaysia. (2012, March 23) Aktiviti LGBT tidak dibenarkan.

Utusan Malaysia. (2012, April 27) LGBT: Mesej jelas Yusof al-Qardhawi.

Utusan Malaysia. (2012, April 23) Lagi program khusus golongan muda.

Utusan Malaysia. (2012, April 27) LGBT: Mesej jelas Yusof al-Qardhawi. 
Utusan Malaysia. (2012, April 28) Semak Dasar Sosial Negara.

Utusan Malaysia. (2012, April 28) Bersih agenda halalkan LGBT?.

Utusan Malaysia. (2012, April 28) LGBT: Kewarasan lawan kegilaan.

Utusan Malaysia. (2012, May 5) LGBT: Akidah sanggup dipermainkan.

Utusan Malaysia. (2012, May 10) LGBT budaya songsang merosakkan sistem sosial, keluarga.

Utusan Malaysia. (2012, June 28). LGBT: Pendirian PAS perlu tegas.

Utusan Malaysia. (2012, June 30) LGBT: Pemimpin pembangkang perlu jelas pendirian.

Utusan Malaysia. (2011, January 3) Seks songsang: Jangan ulangi sejarah umat nabi Lut.

Utusan Malaysia. (2011, August 21) Interview.

Utusan Malaysia. (2011, November 11) Komuniti songsang, agama baru dan hak asasi.

Utusan Malaysia. (2011, December 23) Penularan seks luar tabii semakin serius di kalangan anak muda, Melayu ramai homoseksual?.

Utusan Malaysia. (2010, February 21) Homoseksual menakutkan.

Utusan Malaysia. (2010, December 8) Budaya gay ancam negara.

Utusan Malaysia. (2005, June 10) Ubat cegah HIV/AIDS.

Utusan Malaysia. (2004, July 9) Disebalik gejala gay.

Utusan Malaysia. (2001, February 26) Homoseksual: Penyakit kompleks dan rumit.

Utusan Malaysia. (2000, January 18) Golongan 'mak nyah', lesbian, gay sukar dipulihkan.

Wong, J. (2019, June 19). In a state of denial. The Star Online. Retrieved from https://www.thestar.com.my/opinion/columnists/so-aunty-so-what/2019/06/19/ina-state-of-denial

Yusof, M. I. M., Kadir, M. N. A., Ibrahim, M., \& Puji, T. I. Z. T. (2015). Malaysian Muslim gay and lesbian community's perspective of the concept of domestic partnership and marriage in the Qur'an. Past and Present, 13-24.

Zainon, S., \& Kamila G. (2011). A discursive construction of homosexual males in a Muslimdominant community. Multilingual, 30(3-4), 279-304.

Zulkifli, M. A., \& Rashid, R. A. (2016). A Discursive psychological analysis of Islamic sermons on homosexuality. International Journal of Applied Linguistics and English Literature, 5(6).

Zulkifli, M. A., \& Rashid, R. A. (2019). Discursive strategies employed by homosexual Malaysian Muslim men in talking about homosexuality in Islam. Discourse \& Society, 30(3), 307-320. 